Volodymyr Dzyura

Vehicle Department, Ternopil Ivan Puluj National Technical University, Ukraine, Ternopil,

D. Galytskogo Square 16/29, E-mail: volodymyrdzyura@gmail.com ORCID 0000-0002-1801-2419

\title{
MODELING OF PARTIALLY REGULAR MICRORELIEFS FORMED ON THE END FACES OF ROTATION BODIES BY A VIBRATION METHOD
}

Received: June 06, 2020 / Revised: July 28, 2020 / Accepted: July 31, 2020

(C) Dzyura V., 2020

Abstract. The scheme of formation of a set of variants of grooves of partially regular microreliefs formed on the end faces of rotation bodies by a vibration method has been developed, and the conditions of their existence have been determined. Using a block approach, mathematical models of partially regular microreliefs have been constructed, which described a set of their variants, taking into account such characteristics as the shape of axial lines of continuous regular microroughness, type, and location of axial symmetry lines of grooves, and groove shape. Using MathCAD software and developed mathematical models, graphic images of partially regular microreliefs were obtained.

Keywords: modeling, partially regular microreliefs, end faces, amplitude, pitch, axial symmetry lines, shape, characteristics.

\section{Introduction}

A number of parts of various machines, in particular, tapered variator discs, thrust, tapered, and axial bearings, especially turbocharger combs, which perform their functions with end faces, have high requirements for their wear resistance. These requirements can be provided with vibratory rolling.

Increasing the operational life of machinery and equipment is directly related to ensuring the workability of their working surfaces. Among promising methods of increasing the operational life of the working surfaces of machine parts, there are methods of surface plastic deformation. One of them is vibratory rolling with the formation of a regular microrelief [1].

A fundamental study in the direction of the influence of the parameters of the regular microrelief on the operational properties of the working surfaces of machine parts is the work of Yu. G. Schneider [2].

The researches of the last decades are directed towards a deepening of this direction. They are aimed at improving the operational properties of the working surfaces of individual parts of the units and assemblies of cylinders of internal combustion engines [3], [4], journals of crankshafts and other shafts [5], parts of aircraft and printing equipment [6], [7].

The positive effect of regular microrelief on increasing the operational life of conjugated parts is widely described in the scientific literature. In the work [8] it is noted that the application of a regular microrelief on the inner cylindrical surface of the plunger pair of the rod pump significantly increases the tightness of the movable joint and its operational life. Therefore, the formation of a regular microrelief on the working surfaces of machine parts is an important engineering task that needs to be solved.

\section{Problem Statement}

Ensuring the necessary properties of surfaces with regular microrelief can be done only when modeling it. To do this, it is necessary to calculate the parameters of the microrelief and modes of its formation.

\section{Review of Modern Information Sources on the Subject of the Paper}

For the first time, mathematical models of regular microreliefs (RMR) were described by Yu. G. Schneider in the work [2]. It derives the conditions for the formation of RMR of I-III types. They became the basis for the creation of the standard GOST 24773-81 [1], which regulates the parameters of 
the regular microrelief formed on flat and cylindrical surfaces. He also conducted the first research on the creation of regular microreliefs as decorative processing of the end faces of rotation bodies by a rotation method. The assumptions made by Ya. S. Feldman are used in the development of mathematical models and the calculation of microrelief parameters.

The authors [5] proposed a mathematical model of a regular microrelief with grooves of sinusoidal shape, which is formed on the outer cylindrical surface. The mathematical model involves the construction of various types of microreliefs depending on its initial parameters. The model is visualized in the MathCAD environment.

It should be noted that all mathematical models that describe RMR with grooves of sinusoidal shape are based on the equation of harmonic oscillation and actually duplicate each other. This equation is represented as $y=A \cdot \sin \left(\omega \cdot t+\varphi_{0}\right)$, where $A$ is the amplitude of oscillations, $\omega$ is the cyclic frequency of oscillations, $t$ is the time, and $\varphi_{0}$ is the initial phase of oscillations.

The article [9] presents the results of mathematical modeling of the processing of the outer cylindrical surface of the shaft with a tool with a diamond tip. It forms a regular microrelief on it depending on the processing modes. The results of modeling the surface of the machined part in the process of diamond burnishing with the application of oscillations are obtained. Comparing them with the theoretical results, a conclusion is made about the efficiency of the mathematical model.

In the work [10], the authors proposed the technology of applying a regular microrelief on a flat surface using a CNC milling machine. The equation for the movement of the tool center depending on the input parameters is given. The method of creating a control program for the Siemens and Fanuc computer numerical control systems for applying regular microrelief by plastic deformation on flat surfaces is described. A WinNC simulator developed by EMCO (Austria) was used to visualize the developed microrelief.

The authors [11] also proposed a model developed in the Solid Works environment. It simulates the formation of a regular microrelief of the desired type on cylindrical surfaces depending on the initial data. This model can visualize the formed microrelief and calculate its geometric characteristics.

Mathematical models for different types of regular microreliefs formed on working involute surfaces of cylindrical spur gears have been developed in [12]. However, the shape of the surface is not taken into account in analytical dependencies.

Studies of the process of formation of partially regular microreliefs (PRM) on the end faces of rotation bodies (EFRB), to determine the elements of the mode of vibratory rolling in the literature, except [2], are absent. In the mentioned work, only schemes of vibratory rolling are given and the general features of such method are described.

From the conducted research it is revealed that few publications are devoted to the development of mathematical models of the process of formation of regular microreliefs on the end faces of rotation bodies (EFRB). Therefore, research in this area is relevant.

\section{Objectives and Problems of Research}

The article aims to create mathematical models of partially regular microreliefs formed on the end faces of rotation bodies.

\section{Main Material Presentation}

First of all, it should be noted that the microreliefs formed on the end faces are not completely regular. Their circular pitch at different distances from the center of rotation of the surface will be different. Therefore, they belong to the class of partially regular microreliefs (PRM), a group with continuous regular microroughness (CRM).

Since during the application of PRM on EFRB the formation of a set of variants of PRM grooves is possible due to various shapes of the CRM axial lines, the shape of grooves, type of PRM, mutual arrangement of axial symmetry lines of PRM grooves, it is proposed to use a block approach to build mathematical models describing a set of PRM variants. Its essence is that each feature of the microrelief grooves is described by a system of individual mathematical dependencies. To generate any PRM from a set of possible variants, these mathematical dependencies are combined. 


\section{Volodymyr Dzyura}

The proposed scheme of formation of a set of variants of PRM grooves, formed on EFRB by vibration method, makes it possible to generate a set of variants of PRM grooves with various parameters (Fig. 1).

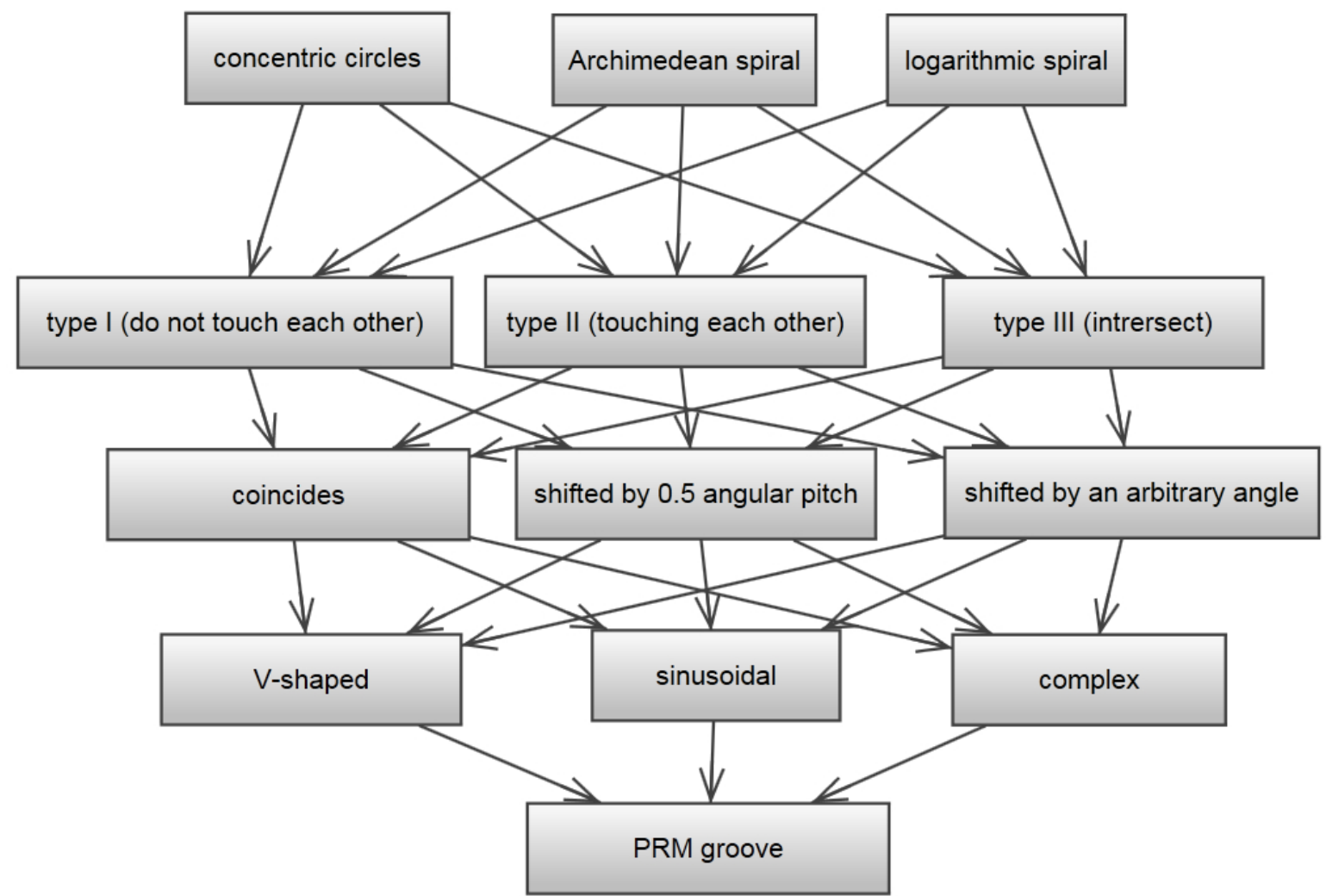

Fig. 1. A scheme of formation of a set of variants of PRM grooves on the end faces of rotation bodies by a vibration method

Each of the parameters that form the characteristics of the grooves has its own mathematical expression (Table 1). Combining them into a system, mathematical models of any variant generated by the scheme of formation of a set of variants of PRM grooves were obtained (Table 2).

The number of formed types of grooves is conditional because the number of possible shapes of grooves or axial lines of CRM can be much larger.

Analytical description of the PRM formed on EFRB using the block approach will allow us to automate calculations of a large number of microrelief parameters, proceeding from possibilities of the technological equipment. This method will simplify the calculations of the relative area of the microrelief, select its parameters, and model the grid depending on the specified parameters.

According to the vibration method of PRM formation, EFRB is given rotational motion, and the deforming element is reciprocated. Geometrical parameters of microrelief grooves and parameters of processing modes should be determined using the rotation angle $\varphi \mathrm{i}$ of this surface. This angle determines the type of microrelief: with grooves whose axes lie on the same line (analog of parallel grooves for RMR, formed on flat or cylindrical surfaces), or with grooves offset by a certain proportion of the angular pitch.

The initial parameters for modeling PRM on EFRB by vibration method are (units are given in parentheses):

- the amplitude $A_{k}$ of the groove (mm);

- the shape of the groove profile;

- the circular pitch of the grooves $S_{k}(\mathrm{~mm})$, or its dependent parameter - the central angle of the groove $\alpha_{k}$ (degrees);

- the axial pitch of the grooves $S_{o}(\mathrm{~mm})$;

- the angular pitch of the grooves $\varphi_{k}$ (degrees);

- the distance from the center of rotation of the end face of the rotation body to the base of the PRM groove element $R_{k}(\mathrm{~mm})$; 
- the radius of the middle line of the grooves, $R_{k c}(\mathrm{~mm})$;

- the radius of the groove imprint, $\rho_{k}(\mathrm{~mm})$;

- the number of the PRM elements $n_{e l}$ (pcs) on the interval $[0 \ldots 2 \pi]$; it is determined by the dependence $n_{e l}=i_{\text {d.s. }} / n_{w}$, where $i_{\text {d.s. }}$ is the number of double strokes of the vibratory roller (d.s./min); $n_{w}$ is the speed of rotation of the workpiece (rpm);

- the parameter characterizing the mutual arrangement of the axial symmetry lines of the grooves $\gamma_{d}$ (degrees); it is determined as the incomplete fraction of the expression $n_{e l}=i_{d . s .} / n_{w}$.

The frequency of oscillations of the deforming element relative to the end face on which the microrelief is formed determines the number of elements of the PRM grooves, which are located at a suitable distance from the center of rotation of the end face of the rotation body $R_{k c}$.

Table 1

Characteristics of axial lines of CRM, shapes and types of PRM grooves formed on the end faces of rotation bodies by a vibration method

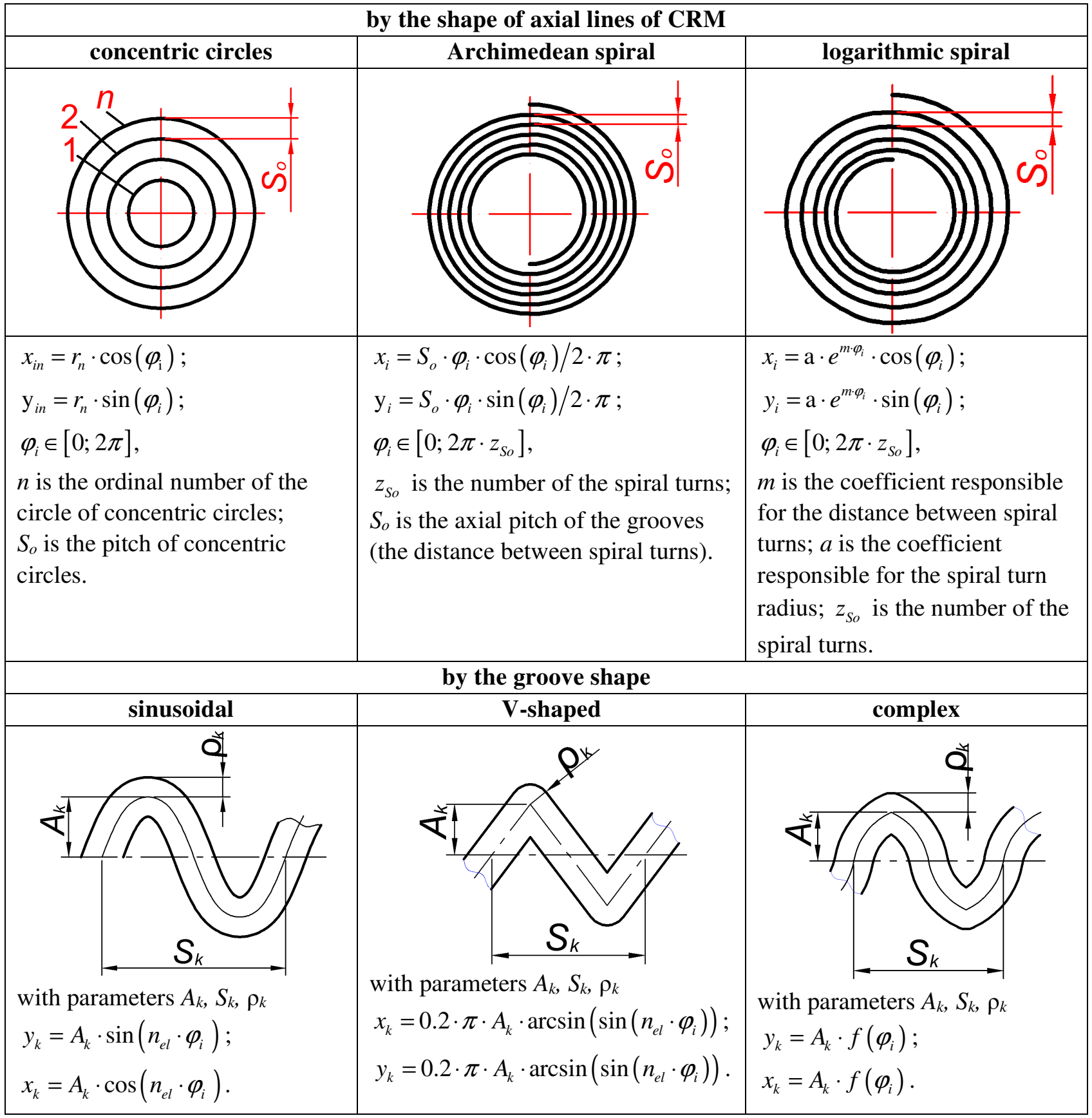


The end of Table 1

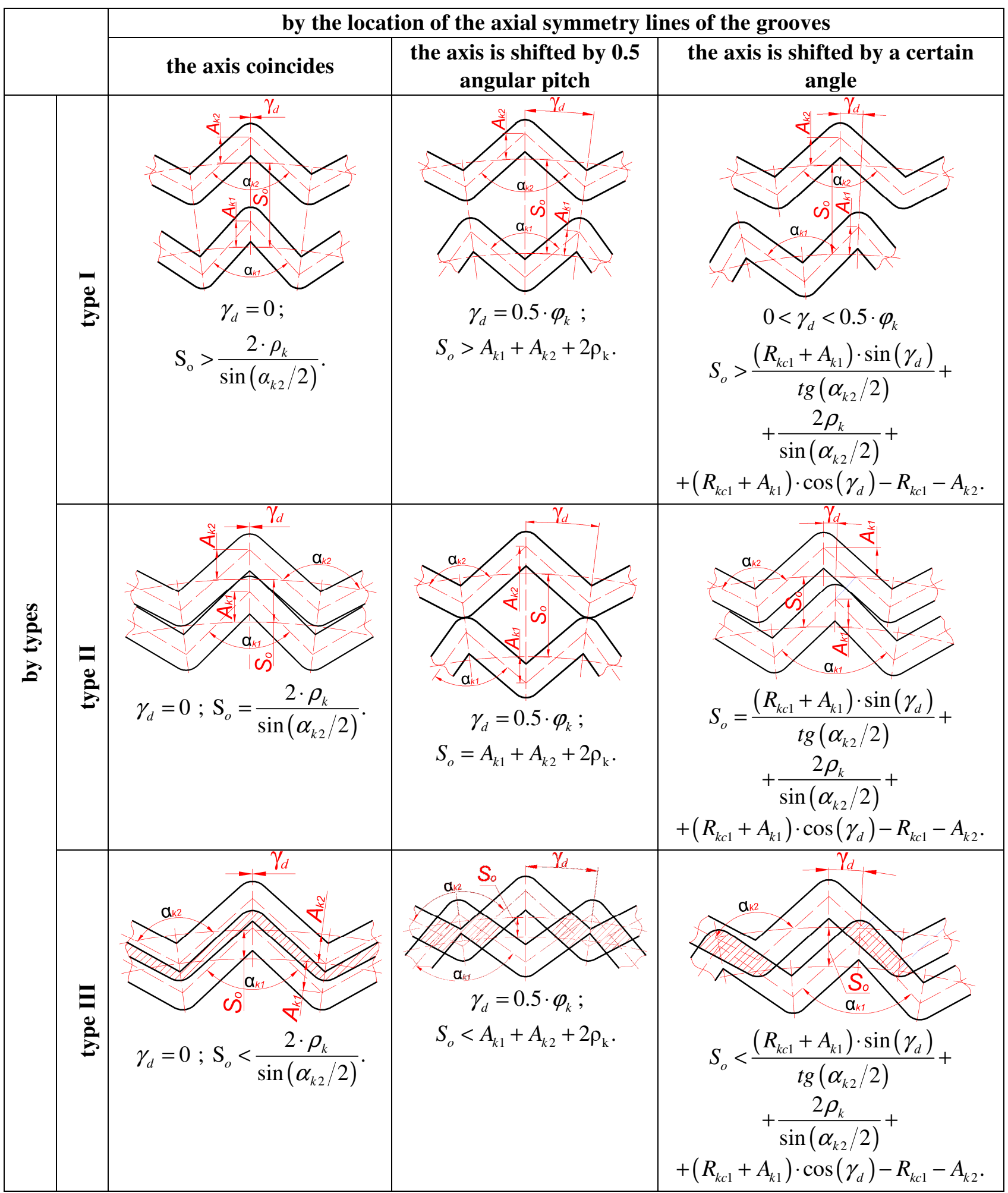

The name of the PRM formed on the EFRB should be formed as follows: the method of forming $\rightarrow$ the shape of the CRM axial lines $\rightarrow$ type $\rightarrow$ the location of the axial symmetry lines of the grooves $\rightarrow$ the shape of the groove. To model the sinusoidal shape of the groove, the function of harmonic oscillations according to the law of sine was used, which was recorded in the form $y_{k}=A_{k} \cdot \sin \left(n_{e l} \cdot \varphi_{i}\right) ; x_{k}=A_{k} \cdot \cos \left(n_{e l} \cdot \varphi_{i}\right)$, where $y_{k}$ and $x_{k}$ are the coordinates of the groove corresponding to the rotation angle $\varphi_{i}$. A function $x_{k}=A_{k} \cdot \arcsin \left(\sin \left(n_{e l} \cdot \varphi_{i}\right)\right), y_{k}=A_{k} \cdot \arcsin \left(\sin \left(n_{e l} \cdot \varphi_{i}\right)\right)$ was used to model the V-shaped groove. It is of 
partially-piecewise type. Its graph consists of linear segments, which alternately acquire extreme values from $-A_{k}$ to $+A_{k}$ at $\varphi_{i}=\varphi_{k} / 2$ and 0 at $\varphi_{i}=\varphi_{k}$.

To confirm the efficiency of the developed mathematical models, we will construct graphic images of PRM of type I for V-shaped and sine-shaped grooves. They are formed on EFRB by a vibration method for various shapes of CRM axial lines and with three variants of arrangement of axial symmetry lines of grooves (Table 2).

Table 2

Variants of partially regular microreliefs formed on the end faces of rotation bodies

\begin{tabular}{|l} 
The name of a partially regular microrelief \\
$\begin{array}{l}\text { Vibrating with performing the CRM axial lines along the Archimedean spiral, sinusoidal, type I } \\
x_{i}=S_{o} \cdot \varphi_{i} \cdot \cos \left(\varphi_{i}\right) / 2 \cdot \pi ; \\
x_{k}=A_{k} \cdot \sin \left(\varphi_{i} \cdot n_{e l}\right) \cdot \cos \left(\varphi_{i}\right)+x_{i} ; \\
y_{k}=A_{k} \cdot \sin \left(\varphi_{i} \cdot n_{e l}\right) \cdot \sin \left(\varphi_{i}\right)+y_{i} \cdot\end{array}$
\end{tabular}

Vibrating with performing the CRM axial lines along the Archimedean spiral, V-shaped, type I

$\left\{\begin{array}{l}x_{i}=S_{o} \cdot \varphi_{i} \cdot \cos \left(\varphi_{i}\right) / 2 \cdot \pi ; \\ \mathrm{y}_{i}=S_{o} \cdot \varphi_{i} \cdot \sin \left(\varphi_{i}\right) / 2 \cdot \pi ; \\ x_{k}=\left(0.2 \cdot \pi \cdot A_{k} \cdot \arcsin \left(\sin \left(n_{e l} \cdot \varphi_{i}\right)\right)\right) \cdot \cos \left(\varphi_{i}\right)+x_{i} ; \\ y_{k}=\left(0.2 \cdot \pi \cdot A_{k} \cdot \arcsin \left(\sin \left(n_{e l} \cdot \varphi_{i}\right)\right)\right) \cdot \sin \left(\varphi_{i}\right)+y_{i} .\end{array}\right.$

(10)

Vibrating with performing the CRM axial lines in concentric circles, sinusoidal, type I

$r_{n+1}=r_{n}+S_{o} ; \quad\left\{\begin{array}{l}x_{i n}=r_{n} \cdot \cos \left(\varphi_{i}\right) ; \\ y_{i n}=r_{n} \cdot \sin \left(\varphi_{i}\right) ; \\ x_{k}=A_{k} \cdot \sin \left(\varphi_{i} \cdot n_{e l}\right) \cdot \cos \left(\varphi_{i}\right)+x_{i} ; \\ y_{k}=A_{k} \cdot \sin \left(\varphi_{i} \cdot n_{e l}\right) \cdot \sin \left(\varphi_{i}\right)+y_{i} .\end{array}\right.$ 
Continuation of Table 2

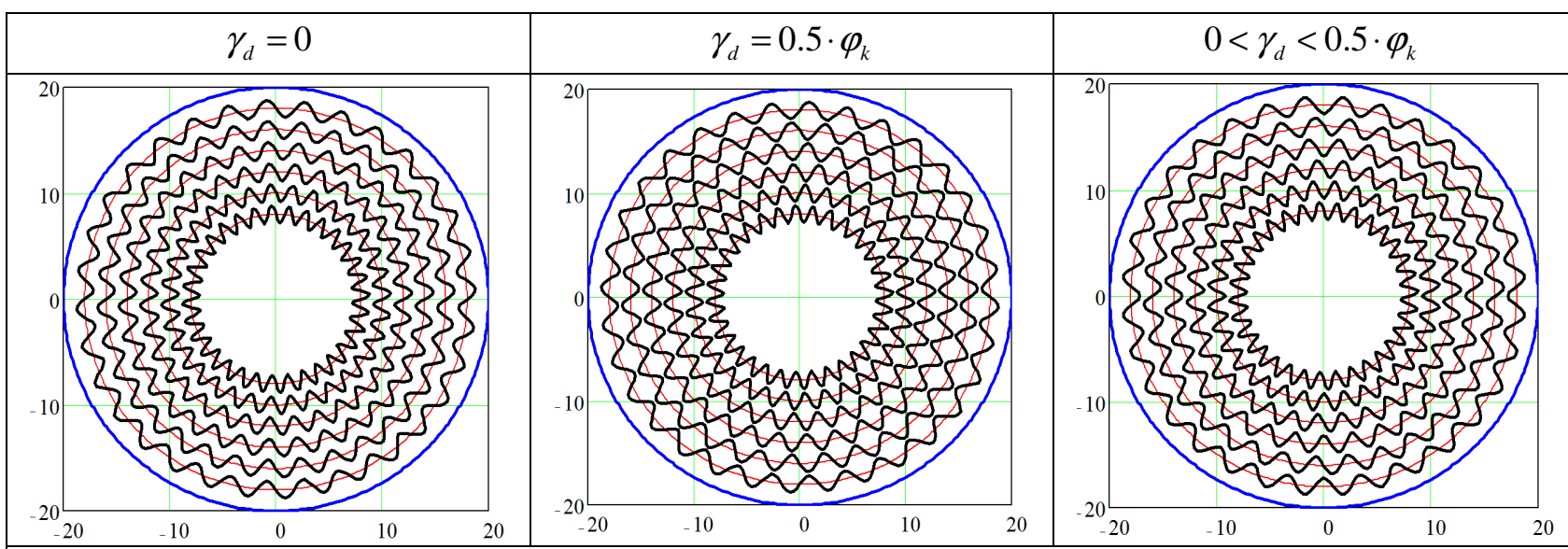

Vibrating with performing the CRM axial lines in concentric circles, V-shaped, type I

$$
r_{n+1}=r_{n}+S_{o} ; \quad\left\{\begin{array}{l}
x_{i n}=r_{n} \cdot \cos \left(\varphi_{i}\right) ; \\
y_{i n}=r_{n} \cdot \sin \left(\varphi_{i}\right) ; \\
x_{k}=0.2 \cdot \pi \cdot A_{k} \cdot \arcsin \left[\sin \left(\left(\varphi_{i}+\gamma_{\partial}\right) \cdot n_{e l}\right)\right] \cdot \cos \left(\varphi_{i}\right)+x_{i} ; \\
y_{k}=0.2 \cdot \pi \cdot A_{k} \cdot \arcsin \left[\sin \left(\left(\varphi_{i}+\gamma_{\partial}\right) \cdot n_{e l}\right)\right] \cdot \sin \left(\varphi_{i}\right)+y_{i} .
\end{array}\right.
$$
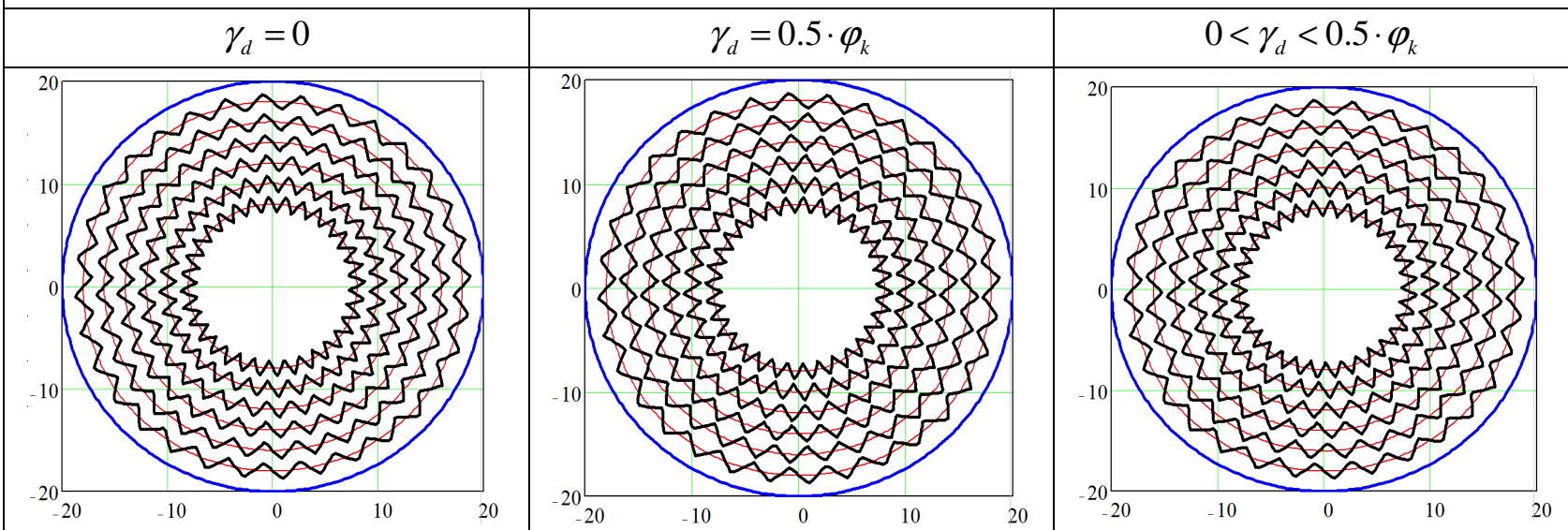

Vibrating with performing the CRM axial lines along a logarithmic spiral, sinusoidal, type I

$x_{i}=a \cdot e^{m \cdot \varphi_{i}} \cdot \cos \left(\varphi_{i}\right)$;

$y_{i}=a \cdot e^{m \cdot \varphi_{i}} \cdot \sin \left(\varphi_{i}\right)$

$x_{k}=A_{k} \cdot \sin \left(\varphi_{i} \cdot n_{e l}\right) \cdot \cos \left(\varphi_{i}\right)+x_{i} ;$

$y_{k}=A_{k} \cdot \sin \left(\varphi_{i} \cdot n_{e l}\right) \cdot \sin \left(\varphi_{i}\right)+y_{i}$.
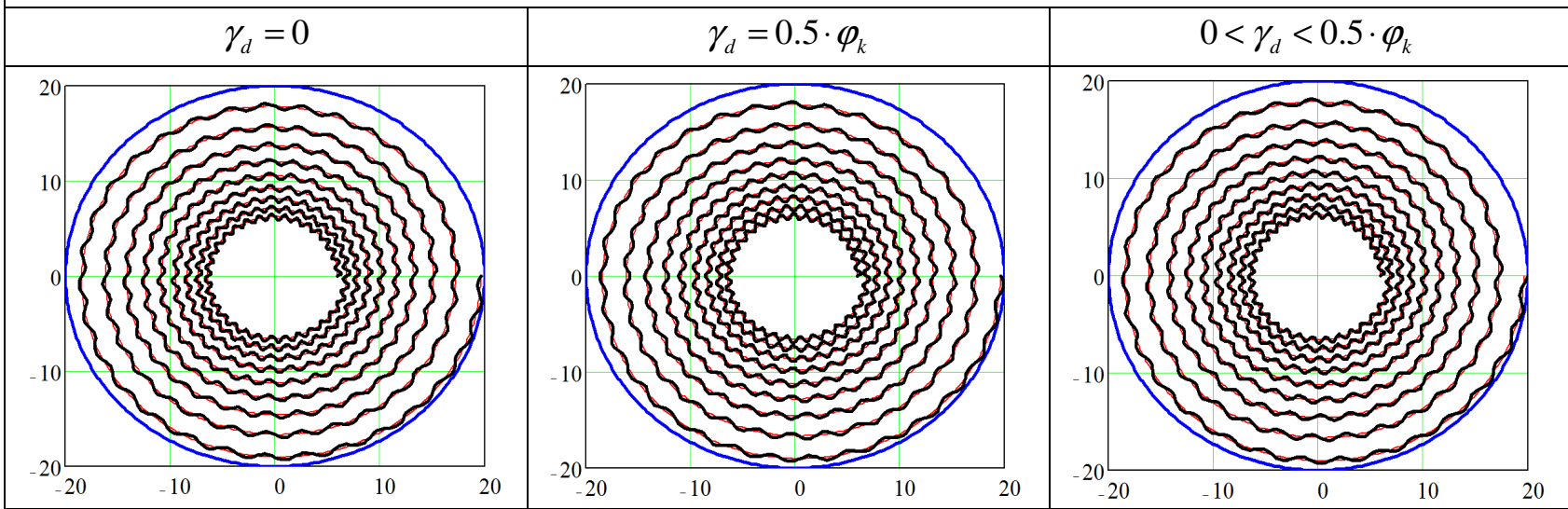


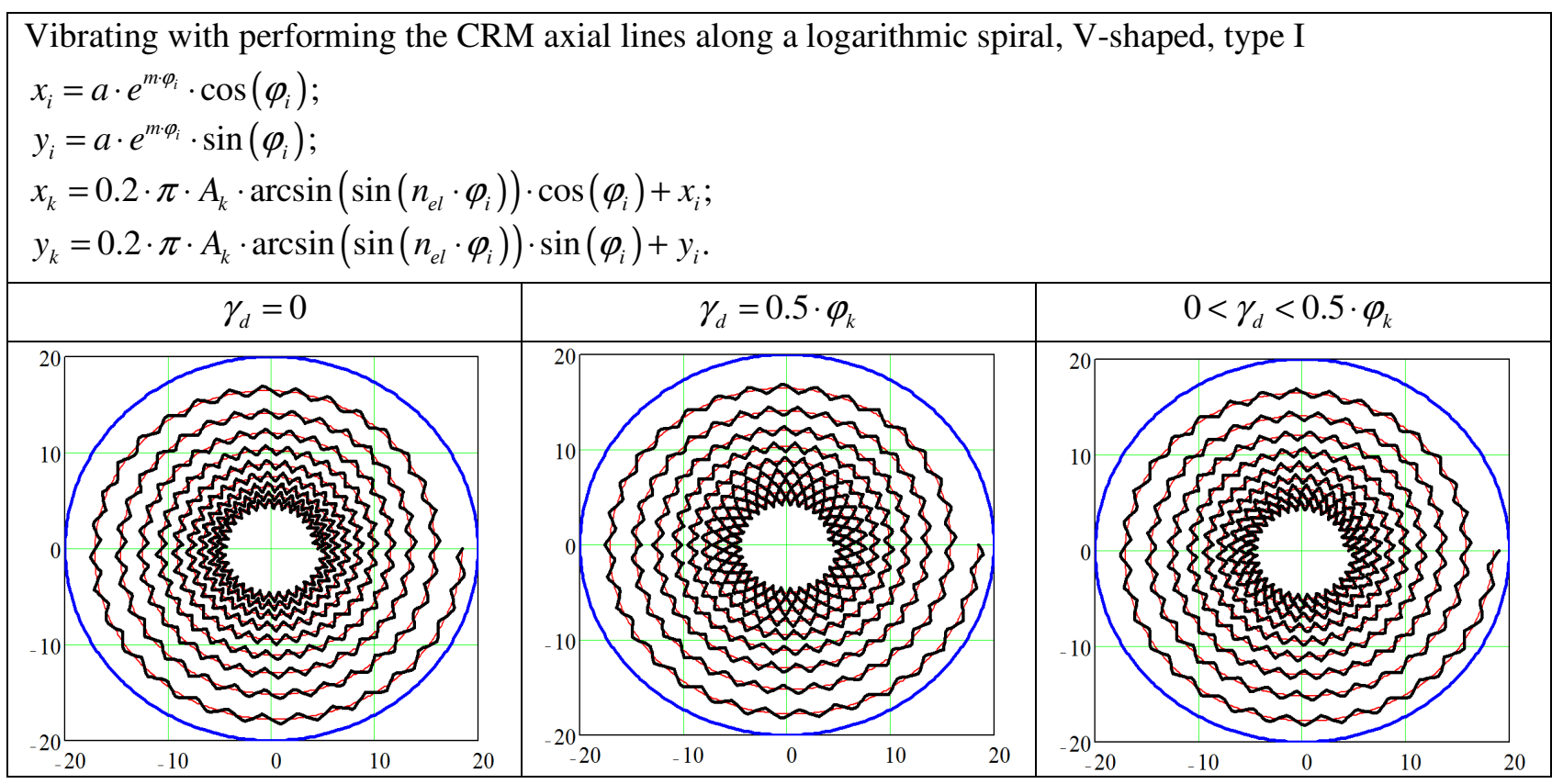

Conclusions

1. For the first time, the characteristics of the grooves of the PRM formed on the end faces of rotation bodies by a vibration method are described using analytical dependencies.

2. Based on the developed set of variants of PRM grooves and with the use of a block approach their mathematical models are developed for the first time. In the future, they will allow you to set the elements of the processing mode and provide the required value of the relative area of vibratory rolling.

3. MathCAD software is used and visualization of microreliefs is carried out based on the received mathematical models.

\section{References}

[1] Poverhnosti s regulyarnyim mikrorelefom. Klassifikatsiya, parametryi i harakteristiki [Surfaces with regular microrelief. Classification, parameters, and characteristics], GOST 24773-81, 1982. [in Russian].

[2] Y. G. Shneider, Ekspluatatsyonnye svoistva detalei s rehuliarnym mykrorelefom [Operational properties of parts with a regular microrelief]. Leningrad, USSR: Mashinostroenie Publ., 1982. [in Russian].

[3] A. S. Lychkovakha, "Povyishenie kachestva obrabotki gilz tsilindrov vnutrennego dvigateley zagoraniya" ["Improving the quality of processing of cylinder liners of internal combustion engines"], Ph.D. dissertation, AzovBlack Sea State Agroengineering Academy, Zernograd, Russia, 2007. [in Russian].

[4] G. V. Chyrkov, "Tekhnolohyia poluchenyia vysokokachestvennykh poverkhnostei otverstyi v detaliakh avtomobylnykh dvyhatelei y druhykh mekhanyzmov" ["Technology for obtaining high-quality surfaces of holes in parts of automobile engines and other mechanisms"], Dvyhatelestroenye [Engine building], vol. 3, pp. 14-15, 2001. [in Russian].

[5] A. N. Kochyn, M. V. Zhelonkyn, and A. A. Holovyn, "Vlyianye rehuliarnoho mykrorelefa na ekspluatatsyonnye pokazately detalei mashyn" ["The influence of regular microrelief on the operational parameters of machine parts"], Trudy Nyzhehorodskoho Hosudarstvennoho Tekhnycheskoho Unyversyteta imeni R.E. Alekseeva [Proceedings of the Nizhny Novgorod State Technical University named after R. E. Alekseev], vol. 3, issue 110, pp. 104-109, 2015. [in Russian].

[6] O. Radionenko, M. Kindrachuk, O. Tisov, and A. Kryzhanovskyi, "Features of transition modes of friction surfaces with partially regular microrelief", Aviation, vol. 22, issue 3, pp. 86-92, 2018. https://doi.org/10.3846/aviation.2018.6204.

[7] P. O. Kyrychok, and A. V. Neskhoziievskyi, "Doslidzhennia vplyvu parametriv mikroreliefu na yakist obrobky detali ta ekspluatatsiini kharakterystyky polihrafichnoho obladnannia" ["Investigation of the influence of microrelief parameters on the quality of detail processing and operational characteristics of printing equipment"]. Tekhnolohichni kompleksy [Technological complexes], vol. 3-4, pp. 74-80, 2007. [in Ukrainian]. 


\section{Volodymyr Dzyura}

[8] R. N. Bakhtizin, K. R. Urazakov, B. M. Latypov, B. H. Ishmukhametov, and A. Y. Narbutovskikh, "The influence of regular microrelief forms on fluid leakage through plunger pair of sucker rod pump", Oil Industry Journal, vol. 4, pp. 113-116, 2017.

[9] P. A. Melnykov, A. N. Pakhomenko, and A. A. Lukianov, "Matematycheskaia model formyrovanyia mykrorelefa sheiky vala pry obrabotke almaznym vyhlazhyvanyem" ["Mathematical model of the formation of the microrelief of the shaft journal during diamond burnishing"], Vektor Nauky Toliattynskoho Hosudarstvennoho Unyversyteta [Science vector of Togliatti state university], vol. 2, issue 32-2, pp. 104-111, 2015. [in Russian].

[10] Y. P. Kuzmyn, K. P. Pompeev, and A. A. Tselyshchev, "Yspolzovanye frezernoho stanka s CHPU dlia nanesenyia rehuliarnoho mykrorelefa na poverkhnosty zahotovky" ["Using a CNC milling machine to apply regular microrelief on the surface of the workpiece"], Izvestyia Vuzov. Pryborostroenye [Journal of Instrument Engineering], vol. 58, issue 4, pp. 273-277, 2015. [in Russian].

[11] A. P. Morhunov, V. A. Hlushets, and Y. M. Strek, "Modelyrovanye protsessa formyrovanyia mnohourovnevoho mykrorelefa poverkhnostnym plastycheskym deformyrovanyem" [Modeling the process of forming a multilevel microrelief by surface plastic deformation], Omskyi Natsyonalnyi Vestnyk [Omsk National Bulletin], vol. 3, issue 36, pp. 79-85, 2006. [in Russian].

[12] P. D. Kryvyi, V. V. Krupa, N. M. Tymoshenko, and A. I. Gural, "Matematychni modeli rehuliarnykh mikroreliefiv na robochykh evolventnykh poverkhniakh tsylindrychnykh priamozubykh kolis" ["Mathematical models of regular microreliefs on working involute surfaces of cylindrical spur gears"], in Proc. Int. Conf. "Actual problems of modern technologies”, Ternopil, Ukraine, November 27-28, 2019, pp. 100-101. [in Ukrainian]. 